\title{
FINANCIAL RISKS ANALYSIS FOR A COMMERCIAL BANK IN THE ROMANIAN BANKING SYSTEM
}

\author{
Imola Drigă ${ }^{1}$
}

\begin{abstract}
The main goal of every bank is managing the risks arising from banking transactions in order to have a profitable activity. Bank managers must identify and manage all risks associated with each business they enter into, since exposure to significant risks reduces the present value of expected future cash flow. The main financial risks associated with the activities of a bank arise as a result of the bank's operations in the financial sector. Financial risks a bank is confronted consist of credit risk, liquidity risk, market risks (interest rate risk and currency risk). Because an inefficient management of financial risks causes the majority of bankruptcies in the banking system, this category of risks has a significant position in the managerial process of any bank. Our paper focuses on assessing the exposure of a commercial bank from the Romanian banking system to financial risks.
\end{abstract}

KEY WORDS: financial risks, credit risk, liquidity risk, interest rate risk, currency risk

JEL CODES: G21, G32

\section{Introduction}

Commercial banks are profit-making organizations acting as intermediaries between borrowers and lenders attracting temporarily available resources from business and individual customers as well as granting loans for those in need of financial support (Bessis, 2002). From this point of view, banks deal with money belonging to persons and other firms assuming a number of risks by performing their activities. Thus, risk is the possibility that a loss will occur and for any businesses it is a part of every decision. In fact, the essence of business decision making is comparing the gains and potential risks involved (Elsinger, et al, 2003).

Risk management in banking involves the process of evaluating the risks faced by a bank and minimizing the costs accordingly. Although any risk classification is subjective, we can distinguish, in essence, two major categories for banking risks (figure no.1.), namely: financial risk that refers to losses arising from financial variables and operating risks concerning losses arising from variables that have impact on the operations of a business (Banks, 2005, p.3).

In this paper, we focus on financial risks comprising of credit risk, liquidity risk, market risk (interest rate risk and currency risk). Financial risks are managed through a process of ongoing identification, measurement and monitoring all type of financial risks the bank is exposed at, Consistency in risk management is ensured through an integrated and methodologically coherent approach to all risks, along with regular monitoring that enables risk management to proactively manage their own portfolios and take corrective actions when necessary (Badea, et al, 2010).

Risk management provides the necessary elements to answer the complexity of risk monitoring. The concept of risk management consists both of preventing and minimising the occurrence of certain events and also in their system of identification, evaluation and quantification. Moreover, the risk management goes through development stages, being of great usefulness nowadays in the implementation of measures for diminishing losses that might occur (Balteş \& Ciuhureanu, 2010, p.69).

\footnotetext{
${ }^{1}$ University of Petrosani, Romania,e-mail: imola.driga@gmail.com
} 
Although risk management is by no means a new concept or initiative, the financial crisis emphasized once more the critical role of risk management in banks. Risk management in banking requires understanding conceptual and implementation issues and examining the latest techniques and practical issue (Bessis, 2009).

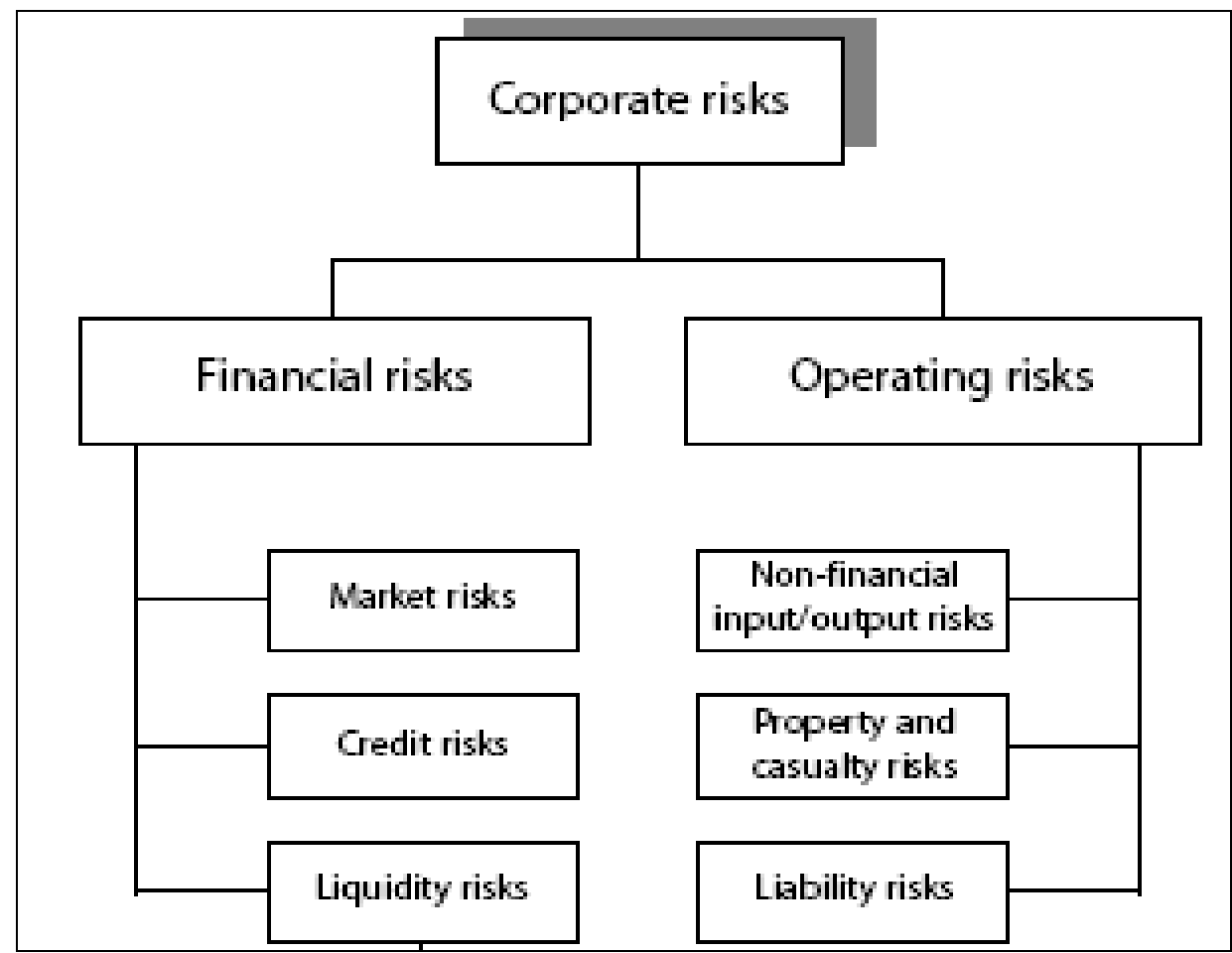

Source: Banks E., 2005. Liquidity Risk. Managing Asset and Funding Risk, Palgrave Macmillan, New York, p.7

Figure no.1. - A general classification of banking risks

\section{Objectives of the study}

The paper is centred on assessing the exposure of a commercial bank from the Romanian banking system to the following financial: credit risk, liquidity risk, interest rate risk and currency risk. In order to identify and assess these financial risks, we have taken into account the indicators for estimating banking risks and data contained in the financial statements of the (appendix 1, 2, 3 and 4). We have determined certain indicators, for two years (year 1 and year 2), that show the overall risk assumed by the bank.

\section{Credit risk analysis}

Lending activity carried out by a bank involves a risk by itself. Thus, the bank is exposed to credit risk through its trading, lending and investing activities and in cases where it acts as an intermediary on behalf of customers or other third parties or it issues guarantees. The bank's primary exposure to credit risk arises through its lending activity. The amount of credit risk exposure in this regard is represented by the carrying amounts of the loans and advances on the balance sheet (Drigă, 2004).

The bank is exposed to credit risk on various other financial assets, including derivative instruments and debt investments, the current credit exposure in respect of these instruments is equal to the carrying amount of these assets in the balance sheet. Credit risk associated with trading and investing activities is managed through the risk management procedures. In order to assess the exposure to this type of risk we can operate with a system of indicators based on information 
obtained from the balance sheet and income statement of the bank (Drigă \& Niță, 2009). Figures used in calculations are provided in appendix 1 and 2.

- the share of loans granted to customers in total assets

$$
\begin{aligned}
& \mathrm{Lo}_{\mathrm{c}} / \mathrm{TA}_{1}=\frac{\mathrm{Lo}_{\mathrm{c}}}{\mathrm{TA}} \cdot 100=\frac{7882238300}{18472482000} \cdot 100=42.67 \% \\
& \mathrm{Lo}_{\mathrm{c}} / \mathrm{TA}_{2}=\frac{\mathrm{Lo}_{\mathrm{c}}}{\mathrm{TA}} \cdot 100=\frac{10288778000}{24489292300} \cdot 100=42.01 \%
\end{aligned}
$$

where: TA - total assets;

$\mathrm{Lo}_{\mathrm{c}}$ - loans granted to customers.

- the share of loans granted to customers in total raised and borrowed sources

$$
\begin{aligned}
& \mathrm{Lo}_{\mathrm{c}} / \mathrm{S}_{\mathrm{rb} 1}=\frac{\mathrm{Lo}_{\mathrm{c}}}{\mathrm{TL}-\mathrm{E}} \cdot 100=\frac{7882238300}{18472482000-3289988300} \cdot 100=51.91 \% \\
& \mathrm{Lo}_{\mathrm{c}} / \mathrm{S}_{\mathrm{rb} 2}=\frac{\mathrm{Lo}_{\mathrm{c}}}{\mathrm{TL}-\mathrm{E}} \cdot 100=\frac{10288778000}{24489292300-3743910700} \cdot 100=49.60 \%
\end{aligned}
$$

where: $\mathrm{S}_{\mathrm{rb}}$ - raised and borrowed sources;

$\mathrm{Lo}_{\mathrm{c}}$ - loans granted to customers;

TL - total liabilities;

E - shareholders' equity.

- the share of investments and loans to other banks in total assets

$$
\begin{aligned}
& \mathrm{Lo}_{\mathrm{bc}} / \mathrm{TA}_{1}=\frac{\mathrm{Lo}_{\mathrm{b}}}{\mathrm{TA}} \cdot 100=\frac{784532100}{18472482000} \cdot 100=4.25 \% \\
& \mathrm{Lo}_{\mathrm{bc}} / \mathrm{TA}_{2}=\frac{\mathrm{Lo}_{\mathrm{b}}}{\mathrm{TA}} \cdot 100=\frac{751640100}{24489292300} \cdot 100=3.07 \%
\end{aligned}
$$

where: TA - total assets;

$\mathrm{Lo}_{\mathrm{b}}$ - investments and loans to other banks.

Based on these data (table 1) we can analyze the exposure of the bank to credit risk, comparing the results for the two periods taken into account (years 1 and year 2).

In year 2 the credit risk records a trend of slight decrease compared to the previous year, given the fact that every indicator registered a downward trend. Thus, the share of loans granted to customers in total assets fell by 0.98 (as shown by the value of $\mathrm{I}^{2 / 1}$, meaning the ratio of values recorded in year 2 and year 1), which shows that the bank was less risky in year 2. In the same year, the share of loans granted to customers in total raised and borrowed sources declines from the previous year by 0.96 .

The largest decline recorded the share of investments and loans to other banks in total assets from a level of $4.25 \%$ recorded in year 1, decreasing to $3.07 \%$ in the following year. In general, we 
can estimate that the credit risk assumed by the bank is lower at the end of the year 2 and the analysis shows that exposure to this type of risk is acceptable, ensuring an adequate profitability in the same time.

Table no.1.

Indicators for measuring credit risk

\begin{tabular}{|c|l|c|c|c|}
\hline \multirow{2}{*}{ No. } & \multicolumn{1}{|c|}{ Indicators } & \multicolumn{2}{|c|}{ Year } & \multirow{2}{*}{$\mathbf{I}^{\mathbf{2} / \mathbf{1}}$} \\
\cline { 3 - 4 } & \multicolumn{1}{|c}{$\mathbf{1}$} & $\mathbf{2}$ & \\
\hline 1. & The share of loans granted to customers in total assets & $42.67 \%$ & $42.01 \%$ & 0.98 \\
\hline 2. & $\begin{array}{l}\text { The share of loans granted to customers in total raised } \\
\text { and borrowed sources }\end{array}$ & $51.91 \%$ & $49.60 \%$ & 0.96 \\
\hline 3. & $\begin{array}{l}\text { The share of investments and loans to other banks in } \\
\text { total assets }\end{array}$ & $4.25 \%$ & $3.07 \%$ & 0.72 \\
\hline
\end{tabular}

Source: own calculations

Note: $I^{2 / 1}$ - represents an index determined as ratio of values recorded in year 2 and year 1

\section{Liquidity risk analysis}

Liquidity risk can be described as the risk of economic loss arising from the inability of the bank to obtain funding at economically reasonable levels so as to cover an expected or unexpected obligation (Banks, 2005, p.4). It is the risk of loss suffered in attempting to ensure the money that is so important to continuing business operations and includes both the risk of being unable to fund assets and the risk of being unable to liquidate an asset in time and at a price close to its fair value. A bank has access to a diverse funding base, using a broad range of instruments including deposits, borrowings and share capital (Dănilă, et al, 2002).

This improves funding flexibility and limits dependence on any type of funding and generally lowers the cost of money. The bank tries to maintain a balance between funding flows and flexibility through the use of certain maturity liabilities. So as to measure liquidity risk and to provide an overall picture on liquidity and liquidity management, we can determine certain indicators (figures from the calculation are provided in appendix 3) (Drigă \& Socol, 2011):

- simple net liabilities (successive) - are determined as difference between liabilities and assets for each maturity band, given the formula:

$$
\mathrm{S}_{\mathrm{nl} i}=\mathrm{L}_{\mathrm{i}}-\mathrm{A}_{\mathrm{i}}
$$

where: $\mathrm{L}_{\mathrm{i}}$ - liabilities for " $\mathrm{i}$ " maturity group;

$\mathrm{A}_{\mathrm{i}}$ - assets for "i" maturity group.

\section{Determination of simple net liabilities for year 1}

Table no.2.

Thousand lei

\begin{tabular}{|c|c|r|r|r|}
\hline No. & Maturity & Assets $\left.\mathbf{~ ( A ~}_{\mathbf{i}}\right)$ & Liabilities ${\left.\mathbf{~} \mathbf{L}_{\mathbf{i}}\right)}^{\text {) }}$ & Simple net liabilities $\mathbf{( \text { Snl } _ { \mathbf { i } } )}$ \\
\hline 1. & $<3$ months & 9981100.3 & 12351245.0 & 2370144.7 \\
\hline 2. & $3-12$ months & 2694863.2 & 1948710.4 & -746152.8 \\
\hline 3. & 1-5 years & 2950822.5 & 665125.8 & -2285696.7 \\
\hline 4. & $>5$ years & 2845696.0 & 3507400.8 & 661704.8 \\
\hline 5. & Total & 18472482.0 & 18472482.0 & 0 \\
\hline
\end{tabular}

Source: own calculations

Note: Simple net liabilities are determined as difference between liabilities and assets for each maturity band: Snl $_{i}=L_{i}$ - $A_{i}$ 
The maturity analysis of simple net liabilities of the bank is presented in table 2 and table 3 .

Determination of simple net liabilities for year 2

Table no.3.

Thousand lei

\begin{tabular}{|c|c|r|r|r|}
\hline No. & Maturity & \multicolumn{1}{c|}{ Assets $\left.\mathbf{( A}_{\mathbf{i}}\right)$} & Liabilities $\left.\mathbf{( L}_{\mathbf{i}}\right)$ & Simple net liabilities $\left(\mathbf{S n l}_{\mathbf{i}} \mathbf{)}\right.$ \\
\hline 1. & $<3$ months & 12628842.6 & 15880401.4 & 3251558.8 \\
\hline 2. & $3-12$ months & 3780438.1 & 2372060.0 & -1408378.1 \\
\hline 3. & $1-5$ years & 4122855.2 & 2374018.9 & -1748836.3 \\
\hline 4. & $>5$ years & 3957156.4 & 3862812.0 & -94344.4 \\
\hline 5. & Total & 24489292.3 & 24489292.3 & 0 \\
\hline
\end{tabular}

Source: own calculations

Note: Simple net liabilities are determined as difference between liabilities and assets for each maturity band: Snl $_{i}=L_{i}$ - $A_{i}$

- cumulated net liabilities - are determined as difference between cumulated liabilities and cumulated assets for each maturity group, given the formula:

$$
\mathrm{C}_{\mathrm{nl}} \mathrm{i}=\mathrm{Cl}_{\mathrm{i}}-\mathrm{Ca}_{\mathrm{i}}
$$

where: $\mathrm{Cl}_{\mathrm{i}}$ - cumulated liabilities for "i" maturity group;

$\mathrm{Ca}_{\mathrm{i}}$ - cumulated assets for " $\mathrm{i}$ " maturity group.

The maturity analysis of cumulated net liabilities of the bank is presented in table 4 and 5 .

\section{Determination of cumulated net liabilities for year 1}

Table no.4.

Thousand lei

\begin{tabular}{|c|c|r|r|r|}
\hline No. & Maturity & $\begin{array}{c}\text { Cumulated assets } \\
\left(\mathbf{C a}_{\mathbf{i}}\right)\end{array}$ & $\begin{array}{c}\text { Cumulated liabilities } \\
\left(\mathbf{C l}_{\mathbf{i}}\right)\end{array}$ & $\begin{array}{c}\text { Cumulated net } \\
\text { liabilities (Cnl } \mathbf{(})\end{array}$ \\
\hline 1. & $<3$ months & 9981100.3 & 12351245.0 & 2370144.7 \\
\hline 2. & $3-12$ months & 12675963.5 & 14299955.4 & 1623991.9 \\
\hline 3. & $1-5$ years & 15626786.0 & 14965081.2 & -661704.8 \\
\hline 4. & $>5$ years & 18472482.0 & 18472482.0 & 0 \\
\hline
\end{tabular}

Source: own calculations

Note: Cumulated net liabilities are determined as difference between cumulated liabilities and cumulated assets for each maturity band: $\mathrm{Cnl}_{i}=\mathrm{Cl}_{i}-\mathrm{Ca}_{i}$

Determination of cumulated net liabilities for year 2

Table no.5.

\begin{tabular}{|c|c|r|r|r|}
\hline No. & Maturity & $\begin{array}{c}\text { Cumulated assets } \\
\left(\mathbf{C a}_{\mathbf{i}}\right)\end{array}$ & $\begin{array}{c}\text { Cumulated liabilities } \\
\left(\mathbf{C l}_{\mathbf{i}}\right)\end{array}$ & $\begin{array}{c}\text { Cumulated net } \\
\text { liabilities (Cnl } \mathbf{~})\end{array}$ \\
\hline 1. & $<3$ months & 12628842.6 & 15880401.4 & 3251558.8 \\
\hline 2. & $3-12$ months & 16409280.7 & 18252461.4 & 1843180.7 \\
\hline 3. & $1-5$ years & 20532135.9 & 20626480.3 & 94344.4 \\
\hline 4. & $>5$ years & 24489292.3 & 24489292.3 & 0 \\
\hline
\end{tabular}

Source: own calculations

Note: Cumulated net liabilities are determined as difference between cumulated liabilities and cumulated assets for each maturity band: $C n l_{i}=C l_{i}-C a_{i}$ 
- liquidity rate - the maturity analysis of liquidity rate of the bank is presented in table 6, 7 .

Determination of liquidity rate for year 1

Table no.6.

\begin{tabular}{|c|c|r|r|r|r|r|}
\hline No. & Maturity & Assets $\left.\mathbf{( A}_{\mathbf{i}}\right)$ & $\begin{array}{c}\text { Liabilities } \\
\left(\mathbf{L}_{\mathbf{i}}\right)\end{array}$ & $\begin{array}{c}\text { Weight } \\
\left(\mathbf{W}_{\mathbf{i}}\right) \\
-\mathbf{y e a r}-\end{array}$ & $\begin{array}{c}\text { Maturity } \\
\text { weighted assets } \\
\left(\mathbf{A}_{\mathbf{i}} \cdot \mathbf{w}_{\mathbf{i}}\right)\end{array}$ & $\begin{array}{c}\text { Maturity } \\
\text { weighted } \\
\text { liabilities } \\
\left(\mathbf{L}_{\mathbf{i}} \cdot \mathbf{w}_{\mathbf{i}}\right)\end{array}$ \\
\hline 1. & $<3$ months & 9981100.3 & 12351245.0 & 0.16 & 1596976.0 & 1976199.2 \\
\hline 2. & $3-12$ months & 2694863.2 & 1948710.4 & 0.625 & 1684289.5 & 1217944.0 \\
\hline 3. & $1-5$ years & 2950822.5 & 665125.8 & 3 & 8852467.5 & 1995377.4 \\
\hline 4. & $>5$ years & 2845696.0 & 3507400.8 & 7.5 & 21342720.0 & 26305506.0 \\
\hline 5. & Total & 18472482.0 & 18472482.0 & - & 33476453.0 & 31495026.6 \\
\hline
\end{tabular}

Source: own calculations

\section{Determination of liquidity rate for year 2}

Table no.7.

\begin{tabular}{|c|c|c|c|c|c|r|}
\hline No. & Maturity & Assets $\mathbf{( A}_{\mathbf{i}} \mathbf{)}$ & $\begin{array}{c}\text { Liabilities } \\
\left(\mathbf{L}_{\mathbf{i}}\right)\end{array}$ & $\begin{array}{c}\text { Weight } \\
\left(\mathbf{w}_{\mathbf{i}}\right) \\
- \text { year }-\end{array}$ & $\begin{array}{l}\text { Maturity } \\
\text { weighted } \\
\text { assets } \\
\left(\mathbf{A}_{\mathbf{i}} \cdot \mathbf{w}_{\mathbf{i}}\right)\end{array}$ & $\begin{array}{c}\text { Maturity weighted } \\
\text { liabilities } \\
\left(\mathbf{L}_{\mathbf{i}} \cdot \mathbf{w}_{\mathbf{i}} \mathbf{)}\right.\end{array}$ \\
\hline 1. & $<3$ months & 12628842.6 & 15880401.4 & 0.16 & 2020614.8 & 2540864.2 \\
\hline 2. & $3-12$ months & 3780438.1 & 2372060.0 & 0.625 & 2362773.8 & 1482537.5 \\
\hline 3. & $1-5$ years & 4122855.2 & 2374018.9 & 3 & 12368565.6 & 7122056.7 \\
\hline 4. & $>5$ years & 3957156.4 & 3862812.0 & 7.5 & 29678673.0 & 28971090.0 \\
\hline 5. & Total & 24489292.3 & 24489292.3 & - & 46430627.2 & 40116548.4 \\
\hline
\end{tabular}

Source: own calculations

From data presented in table 6 and 7, we can determine the liquidity rate for year 1 and 2.

$$
\begin{aligned}
L R_{1} & =\frac{\sum_{i=1}^{n} L_{i} \cdot w_{i}}{\sum_{i=1}^{n} A_{i} \cdot w_{i}}=\frac{1976199200+1217944000+1995377400+26305506000}{1596976000+1684289500+8852467500+21342720000}=0.94 \\
L_{2}= & \frac{\sum_{\mathrm{i}=1}^{\mathrm{n}} \mathrm{L}_{\mathrm{i}} \cdot \mathrm{w}_{\mathrm{i}}}{\sum_{\mathrm{i}=1}^{\mathrm{n}} \mathrm{A}_{\mathrm{i}} \cdot \mathrm{w}_{\mathrm{i}}}=\frac{2540864200+1482537500+7122056700+28971090000}{2020614800+2362773800+12368565600+29678673000}=0.86
\end{aligned}
$$

where: $\mathrm{L}_{\mathrm{i}}$ - liabilities with "i" maturity;

$A_{i}$ - assets with "i" maturity;

$\mathrm{w}_{\mathrm{i}}$ - weight for "i $\mathrm{i}$ " maturity. 
- the average maturity of assets

$$
\begin{aligned}
t_{A 1}= & \frac{\sum_{i=1}^{n} A_{i} \cdot w_{i}}{T A}=\frac{33476453000}{18472482000}=1.81 \text { years }=21.75 \text { months }=652.4 \text { days } \\
t_{A 2}= & \frac{\sum_{i=1}^{n} A_{i} \cdot w_{i}}{T A}=\frac{46430627200}{24489292300}=1.90 \text { years }=22.75 \text { months }=682.5 \text { days }
\end{aligned}
$$

where: $w_{i}$ - weight for " $i$ " maturity;

$A_{i}$ - assets with "i" maturity;

TA - total assets.

- the average maturity of liabilities

$$
\begin{aligned}
& t_{L_{1}}=\frac{\sum_{i=1}^{n} L_{i} \cdot w_{i}}{T L}=\frac{31495026600}{18472482000}=1.70 \text { years }=20.46 \text { months }=613.8 \text { days } \\
& t_{L_{2}}=\frac{\sum_{i=1}^{n} L_{i} \cdot w_{i}}{T L}=\frac{40116548400}{24489292300}=1.64 \text { years }=19.66 \text { months }=589.7 \text { days }
\end{aligned}
$$

where: $\mathrm{w}_{\mathrm{i}}$ - weight for " $\mathrm{i}$ " maturity;

$\mathrm{L}_{\mathrm{i}}$ - liabilities with "i" maturity;

TL - total liabilities.

- average maturities transformation

$$
\begin{aligned}
& T_{m 1}=t_{A}-t_{L}=652.4-613.8=38.6 \text { days } \\
& T_{m 2}=t_{A}-t_{L}=682.5-589.7=92.8 \text { days }
\end{aligned}
$$

where: $t_{L}$ - average maturity of liabilities;

$t_{A}$ - average maturity of assets.

- loans granted to customers / customer deposits formed

$$
\begin{aligned}
& L o_{c} / D_{c 1}=\frac{L_{c}}{D_{c}}=\frac{7882238300}{13953887900}=0.565 \\
& L o_{c} / D_{c 2}=\frac{L_{c}}{D_{c}}=\frac{10288778000}{17597087700}=0.585
\end{aligned}
$$

where: $D_{c}$ - deposits formed by customers;

$\mathrm{Lo}_{\mathrm{c}}$ - loans granted to customers. 
- immediate liquidity

$$
\begin{aligned}
& I L_{1}=\frac{P_{b}+S}{S_{r b}} \cdot 100=\frac{7805882300}{15182493700} \cdot 100=51.41 \% \\
& I L_{2}=\frac{P_{b}+S}{S_{r b}} \cdot 100=\frac{11292001700}{20745381600} \cdot 100=54.43 \%
\end{aligned}
$$

where: S - investment securities;

$\mathrm{P}_{\mathrm{bc}}$ - placements with banks;

$\mathrm{S}_{\mathrm{rb}}$ - raised and borrowed sources.

We can asses the exposure of the bank to liquidity risk (based on data from table 8) by comparing results for both years considered. The liquidity risk is almost nonexistent because all indicators recorded values close to the optimum level.

Indicators for measuring liquidity risk

\begin{tabular}{|c|l|c|c|c|c|}
\hline \multirow{2}{*}{ No. } & \multicolumn{1}{|c|}{ Indicators } & \multirow{2}{*}{ U.M. } & \multicolumn{2}{|c|}{ Year } & \multirow{2}{*}{$\mathbf{I}^{\mathbf{2} \mathbf{1}}$} \\
\cline { 4 - 5 } & & & $\mathbf{1}$ & $\mathbf{2}$ & \\
\hline 1. & Liquidity rate & - & 0.94 & 0.86 & 0.91 \\
\hline 2. & Average maturity of assets & days & 652.4 & 682.5 & 1.05 \\
\hline 3. & Average maturity of liabilities & days & 613.8 & 589.7 & 0.96 \\
\hline 4. & Average maturities transformation & days & 38.6 & 92.8 & 2.40 \\
\hline 5. & $\begin{array}{l}\text { Loans granted to customers / customer } \\
\text { deposits formed }\end{array}$ & - & 0.565 & 0.585 & \multirow{2}{*}{1.04} \\
\hline 6. & Immediate liquidity & $\%$ & 51.41 & 54.43 & 1.06 \\
\hline
\end{tabular}

Source: own calculations

Note: $I^{2 / 1}$ - represents an index determined as ratio of values in year 2 and year 1

Hence, values recorded in year 1 and 2 by the liquidity rate were lower than 1, being close to this optimum level. Thus, exposure to liquidity risk is very low. In terms of investments' profitability, these values show that ensuring a low liquidity risk does not affect profitability.

Examining the average maturities of assets and liabilities, we can see that in year 2 the average maturity for assets is higher than for liabilities, leading to the conclusion that the bank is funded on short-term compared with the maturity of its resources. Thus, liabilities reach maturity faster than investments. Since the difference between these values is not too high, we can conclude that the bank efficiently manages liquidity risk (Drigă \& Socol, 2011, p.53).

The average maturities transformation is the most edifying indicator for liquidity risk since it expresses the actual expression of the transformation used. This indicator (38.6 days in year 1 and 92.8 days in year 2) points out an average period of time in which resources come to maturity faster than investments, requiring funding if resources are not extending. The relation between credits and deposits is less relevant, expressing the degree of coverage for investments through raised resources. A value lower than 1, registered in both years, proves an appropriate management of liquidity risk (Drigă \& Socol, 2011, p.53). 


\section{Interest rate risk analysis}

A bank incurs interest rate risk principally in the form of exposure to adverse changes in the market interest rates to the extent that interest-earning assets and interest-earning liabilities mature or reprice at different times or in differing amounts.

Asset-liability risk management is developed taking into account the sensitivity of the bank to interest rate changes. In general, the bank is liability sensitive because its interest-earning assets have a longer duration and reprice less frequently than interest-bearing liabilities. Given the data in the financial statements of the bank (appendix 3), we can determine the following indicators (Drigă, 2007):

- GAP - is determined as difference between assets and liabilities sensitive to interest rate changes, given the formula:

$$
\mathrm{GAP}=\mathrm{A}_{\mathrm{s}}-\mathrm{L}_{\mathrm{s}}
$$

where: $\mathrm{L}_{\mathrm{s}}$ - liabilities sensitive to interest rate changes;

$A_{s}$ - assets sensitive to interest rate changes.

- cumulated GAP during period $t\left(G A P_{c}\right)$ - highlights the interest rate risk for the entire period and it is determined as follows:

$$
\mathrm{GAP}_{\mathrm{c}}=\mathrm{GAP}_{\mathrm{t}}+\mathrm{GAP}_{\mathrm{ct}-1}
$$

where: $\mathrm{GAP}_{\mathrm{c} t-1}$ - cumulated GAP during period $\mathrm{t}-1$;

$\mathrm{GAP}_{\mathrm{t}}$ - GAP during period $\mathrm{t}$.

- GAP rate $\left(R_{G A P}\right)$ - summarizes cumulative differences between assets and liabilities for a given range of maturity, being calculated based on the following formula:

$$
\mathrm{R}_{\mathrm{GAP}}=\frac{\mathrm{GAP}_{\mathrm{c}}}{\mathrm{TA}} \cdot 100
$$

where: TA - total assets ;

$\mathrm{GAP}_{\mathrm{c}}$ - cumulated GAP.

- sensitivity rate $\left(R_{s}\right)$ - is determined as a ratio between assets and liabilities sensitive to interest rate changes, given the formula:

$$
\mathrm{R}_{\mathrm{s}}=\frac{\mathrm{A}_{\mathrm{s}}}{\mathrm{P}_{\mathrm{s}}}
$$

where: $L_{s}$ - liabilities sensitive to interest rate changes;

$A_{\mathrm{s}}$ - assets sensitive to interest rate changes.

Based on data from table 9, we can conclude that, for the first maturity band (up to 3 months), the GAP is negative (the bank has more liabilities sensible to interest rate changes than assets), which means that when the interest rate increases the net interest-earnings diminish. The gap is quite significant in the year 2, the indicator recording a higher value with 1.37 than in the 
previous year (as shown by the value of $\mathrm{I}^{2 / 1}$, meaning the ratio of values recorded in year 2 and year $1)$.

For the following maturity bands (3-12 months, 1-5 years), the GAP is positive, which shows that the bank has more assets sensible to interest rate changes than liabilities and a decrease in the level of the interest rate determines a decrease in the net interest-earnings.

Table no.9.

Indicators for measuring interest rate risk

\begin{tabular}{|c|c|c|c|c|c|c|c|}
\hline \multirow[b]{2}{*}{ No. } & \multirow[b]{2}{*}{ Indicator } & \multirow[b]{2}{*}{ U.M. } & \multirow[b]{2}{*}{ Year } & \multicolumn{4}{|c|}{ Maturity } \\
\hline & & & & $\begin{array}{c}1-3 \\
\text { months }\end{array}$ & $\begin{array}{c}\text { 3-12 } \\
\text { months }\end{array}$ & 1-5 years & I.r. \\
\hline \multirow{3}{*}{1.} & \multirow{3}{*}{ GAP } & \multirow{2}{*}{$\begin{array}{c}\text { thousand } \\
\text { lei }\end{array}$} & 1 & -2370144.7 & 746152.8 & 2285696.7 & -661704.8 \\
\hline & & & 2 & -3251558.8 & 1408378.1 & 1748836.3 & 94344.4 \\
\hline & & - & $I^{2 / 1}$ & 1.37 & 1.89 & 0.77 & -0.14 \\
\hline \multirow{3}{*}{2.} & \multirow{3}{*}{$G A P_{c}$} & \multirow{2}{*}{$\begin{array}{c}\text { thousand } \\
\text { lei }\end{array}$} & 1 & -2370144.7 & -1623991.9 & 661704.8 & - \\
\hline & & & 2 & -3251558.8 & -1843180.7 & -94344.4 & - \\
\hline & & - & $I^{2 / 1}$ & 1.37 & 1.13 & -0.14 & - \\
\hline \multirow{3}{*}{3.} & \multirow{3}{*}{$\mathrm{I}_{\mathrm{GAP}}$} & \multirow{2}{*}{$\%$} & 1 & -12.83 & -8.79 & 3.58 & - \\
\hline & & & 2 & -13.28 & -7.53 & -0.39 & - \\
\hline & & - & $I^{2 / 1}$ & 1.03 & 0.86 & -0.11 & - \\
\hline \multirow{3}{*}{4.} & \multirow{3}{*}{$\mathrm{I}_{\mathrm{S}}$} & \multirow{3}{*}{ - } & 1 & 0.81 & 1.38 & 4.44 & 0.81 \\
\hline & & & 2 & 0.80 & 1.59 & 1.74 & 1.02 \\
\hline & & & $I^{2 / 1}$ & 0.98 & 1.15 & 0.39 & 1.26 \\
\hline
\end{tabular}

Source: own calculations

Note: $I^{2 / 1}$ - represents an index determined as ratio of values recorded in year 2 and year 1 ; I.r.- insensible to the modification rate

\section{Currency risk analysis}

A bank is exposed to currency risk through transactions in foreign currencies against lei. There is also a balance sheet risk that the net monetary liabilities in foreign currencies will take a higher value or the monetary assets in foreign currencies will take a lower value when translated into lei as a result of currency movements. The principal foreign currencies held by the bank from our study are EUR and USD (Badea, et al, 2010).

The bank manages its exposure to movements in exchanges rates by modifying its assets and liabilities mix. Open foreign exchange positions (FEP) represent a source of foreign exchange risk. In order to avoid losses arising from adverse movements in exchange rates, the bank is currently pursuing the policy of maintaining an overall long foreign exchange position (FEP). In order to assess the exposure to this type of risk we can operate with a system of indicators based on information obtained from the financial statements (appendix 4) (Drigă, 2007).

- individual foreign exchange positions

$$
\begin{gathered}
F E P_{U S D ~ 1}=A_{U S D}-L_{U S D}=3780286900-3103240900=677046000 \mathrm{lei} \\
F E P_{U S D 2}=A_{U S D}-L_{U S D}=4384088400-4104241800=279846600 \mathrm{le} i \\
F E P_{E U R_{1}}=A_{E U R}-L_{E U R}=2945997800-3208789700=-262791900 \mathrm{lei} \\
F E P_{E U R 2}=A_{E U R}-L_{E U R}=4975773200-5095610100=-119836900 \mathrm{lei}
\end{gathered}
$$


where: $A_{\mathrm{EUR}}$ - total assets in EUR;

$\mathrm{L}_{\mathrm{EUR}}$ - total liabilities in EUR;

$\mathrm{A}_{\mathrm{USD}}$ - total assets in USD;

$\mathrm{L}_{\mathrm{USD}}$ - total liabilities in USD.

- overall foreign exchange positions

$$
\begin{aligned}
& F E P o_{1}=F E P_{l}-F E P_{s}=754781400-262791900=491989500 \text { lei } \\
& F E P o_{2}=F E P_{l}-F E P_{l s}=279846600-128631900=151214700 l e i
\end{aligned}
$$

where: $\mathrm{FEP}_{\mathrm{s}}$ - short foreign exchange position;

$\mathrm{FEP}_{1}$ - long foreign exchange position.

Analyzing data from table 10, we can conclude that the bank has a short position for EUR at the end of both years, meaning that liabilities in this currency exceed assets, but for USD the bank has a long position.

Indicators for measuring currency risk

Table no.10.

Thousand lei

\begin{tabular}{|c|l|c|c|c|c|}
\hline \multirow{2}{*}{ No. } & \multicolumn{1}{|c|}{ Indicator } & \multirow{2}{*}{ Currency } & \multicolumn{2}{|c|}{ Year } & \multirow{2}{*}{$\mathbf{I}^{\mathbf{2} / \mathbf{1}}$} \\
\cline { 3 - 5 } & & $\mathbf{1}$ & $\mathbf{2}$ & 0,41 \\
\hline \multirow{2}{*}{1.} & $\begin{array}{l}\text { Individual foreign exchange } \\
\text { positions }\end{array}$ & USD & 677046,0 & 279846,6 & 0,46 \\
\cline { 2 - 5 } 2. & $\begin{array}{l}\text { Global foreign exchange } \\
\text { positions }\end{array}$ & - & $-262791,9$ & $-119836,9$ & $0,4989,5$ \\
\hline
\end{tabular}

Source: own calculations

Note: $I^{2 / 1}$ - represents an index determined as ratio of values in year 2 and year 1

The values of the overall foreign exchange positions recorded in both years shows that assets in foreign currency exceed liabilities in foreign currency, so the bank is able to maintaining an overall long foreign exchange position in order to avoid currency risk.

\section{Conclusion}

Banking risk is a phenomenon that occurs during the development of banking operations and causing negative effects on the business. Financial risks are the only risks that can be evaluated through a system of indicators. Other types of risks are generated by exogenous factors over which the bank has limited or no control. Financial risks are due to permanent imbalances that occur between bank assets and liabilities over which the bank management has control.

Basically, financial risks include two types of risks: pure risks that can result in a loss if not properly managed (including liquidity risk and credit risk) and speculative/impure risks represented mainly by interest rate risk and currency risk.

In the paper we presented an analysis of financial risks for a bank taking into account two periods (year 1 and year 2). The study shows that the bank considered is a stable institution and has excellent perspectives.

Thus:

- the exposure to credit risk is acceptable in both years, and further more in year 2 the credit risk records a trend of slight decrease compared to the previous year, given the fact that every relevant indicator registered a downward trend; 
- liquidity risk is appropriately managed by the bank, maintaining a proper liquidity in order to cover financial commitments, ensuring an appropriate profitability in the same time; a proper balance sheet structure is insured so as the bank is able to minimize potentially negative effects;

- in terms of interest rate risk, the bank recorded a low exposure by setting an appropriate structure of its assets and liabilities, enabling it to avoid significant negative impact on its activity and financial performance, in case the interest rates change;

- the exposure to credit risk is low in both years because the bank is able to maintaining an overall long foreign exchange position in order to avoid currency risk.

We can conclude that the exposure of the bank to the main types of financial risks is between acceptable limits, enabling the bank to achieve high incomes in the same time.

\section{References}

1. Alexander C., 2005. The Present and Future of Financial Risk Management, Journal of Financial Econometrics, Vol.3, Issue 1.

2. Badea L., Socol A., Drăgoi V., Drigă, I., 2010. Risk Management in Banking, Economic Publishing House, Romania.

3. Balteş N., Ciuhureanu A.T., 2010. Study on the Risk Management in Banking Institutions, Studies in Business and Economics, vol.5 (3), pp. 67-78.

4. Banks E., 2005. Liquidity Risk. Managing Asset and Funding Risk, Palgrave Macmillan, New York.

5. Basno C., Dardac N., 2002. Bank Management, Economic Publishing House, Romania.

6. Bessis J., 2009. Risk Management in Banking, Third Edition, John Wiley \& Sons Ltd., USA.

7. Christoffersen P., Goncalves S., 2005. Estimation Risk in Financial Risk Management, Journal of Risk, Vol.7, No.3.

8. Dănilă N., Anghel L., Dănilă M., 2002. Bank Liquidity Management, Economic Publishing House, Romania.

9. Drigă I., Socol A., 2011. Liquidity Risk Management in Banking, The Young Economists Journal, Year VII - No.13s, Special Issue, pp.46-55.

10. Drigă I., Niţă D., 2009. Indicators for assesing banking risks, Studia Universitas „Vasile Goldiş" Arad, Seria Ştiințe Economice, part I, pp.680-691.

11. Drigă I., 2007. Risks Analysis and Management in Banking, Universitas Publishing House.

12. Drigă I., 2004. Means of Reducing Credit Risk, Annals of the University of Petroşani, Economics, vol.IV, pp.69-74.

13. Elsinger H., Lehar A., Summer M., 2003. Risk Assessment for Banking Systems, 14th Annual Utah Winter Finance Conference Paper no.437, USA.

14. Iliescu C., 2003. Risk Management, Dacia Publishing House, Cluj-Napoca, Romania.

15. Jorion P., 2007. Financial Risk Manager Handbook, Fourth Edition, John Wiley \& Sons, Inc., Hoboken, New Jersey.

16. Laeven L., 2004. Banking Risks around the World, World Bank Policy Research Working Paper, USA.

17. Njanike K., 2009. The Impact of Effective Credit Risk Management on Bank Survival, Annals of the University of Petroşani, Economics, 9(2), pp.173-184.

18. Nițu I., 2000. Bank Risk Management, Expert Publishing House, Romania.

19. Olteanu A., Olteanu F.M., Badea L., 2003. Bank Management. Characteristics, Strategies, Cases, Dareco Publishing House, Romania.

20. Socol A., 2007. Qualitative and quantitative aspects of operational banking risk in Romania, Annales Universitatis Apulensis, Series Oeconomica, no.9, pp.126-134. 
The balance sheet of the commercial bank

Appendix 1

\begin{tabular}{|l|r|r|}
\hline \multirow{2}{*}{} & \multicolumn{2}{c|}{ Yhousand lei } \\
\cline { 2 - 3 } & \multicolumn{1}{|c|}{$\mathbf{1}$} & \multicolumn{1}{c|}{$\mathbf{2}$} \\
\hline I. Total assets & 18472482.0 & 24489292.3 \\
\hline 1. Cash and cash equivalents & 435560.8 & 412358.6 \\
\hline 2. Current accounts and placements with central banks & 5289853.7 & 7059188.4 \\
\hline 3. Investments at banks & 752067.1 & 721120.5 \\
\hline 4. Loans granted to banks & 32465.0 & 30519.6 \\
\hline 5. Loans granted to customers & 7882238.3 & 10288778.0 \\
\hline 6. Financial assets & 2268601.3 & 4130209.9 \\
\hline 7. Tangible assets & 1672204.2 & 1695479.3 \\
\hline 8. Intangible assets & 71014.4 & 88964.1 \\
\hline 9. Other assets & 68477.2 & 62673.9 \\
\hline II. Total liabilities & 18472482.0 & 24489292.3 \\
\hline 1. Deposits from banks & 130773.5 & 510050.8 \\
\hline 2. Deposits from customers & 13953887.9 & 17597087.7 \\
\hline 3. Loans from banks and other financial institutions & 963715.4 & 2375161.2 \\
\hline 4. Other liabilities & 134116.9 & 263081.9 \\
\hline 5. Issued capital & 2119692.5 & 2119692.5 \\
\hline 6. Reserves & 693259.2 & 735211.8 \\
\hline 7. Retained earnings & 477036.6 & 889006.4 \\
\hline
\end{tabular}

Source: Financial statements of the bank for year 1 and year 2

The income statement of the commercial bank

Appendix 2

Thousand lei

\begin{tabular}{|l|r|r|}
\hline \multirow{2}{*}{ I. Total income } & \multicolumn{2}{|c|}{ Year } \\
\cline { 2 - 3 } & \multicolumn{1}{|c|}{$\mathbf{1}$} \\
\hline 1. Net interest income & 1759914.9 & 2142894.0 \\
\hline 2. Net fee and commission income & 1066331.7 & 1322833.7 \\
\hline 3. Net trading income & 532190.5 & 566205.0 \\
\hline 4. Other revenues & 67571.8 & 118716.6 \\
\hline II. Total expenses & 93820.9 & 135138.7 \\
\hline 1. Operating expenses & 1377634.8 & 1311360.4 \\
\hline 2. Depreciation and impairment of property and equipment & 1038150.0 & 1104952.3 \\
\hline 3. Loss on net monetary position & 161251.7 & 206408.1 \\
\hline III. Profit before tax & 178233.1 & 0.0 \\
\hline IV. Net profit & 382280.1 & 831533.6 \\
\hline
\end{tabular}

Source: Financial statements of the bank for year 1 and year 2 


\section{The situation of assets and liabilities for each maturity band for the commercial bank}

Appendix 3

Thousand lei

\begin{tabular}{|c|c|r|r|r|r|}
\hline \multirow{2}{*}{ No. } & \multirow{2}{*}{ Maturity } & \multicolumn{4}{|c|}{ Year } \\
\cline { 3 - 6 } & & \multicolumn{1}{|c|}{ Assets } & Liabilities & \multicolumn{1}{c|}{ Assets } & \multicolumn{1}{c|}{ Liabilities } \\
\hline 1. & $<3$ months & 9981100.3 & 12351245.0 & 12628842.6 & 15880401.4 \\
\hline 2. & $3-12$ months & 2694863.2 & 1948710.4 & 3780438.1 & 2372060.0 \\
\hline 3. & $1-5$ years & 2950822.5 & 665125.8 & 4122855.2 & 2374018.9 \\
\hline 4. & $>5$ years & 2845696.0 & 3507400.8 & 3957156.4 & 3862812.0 \\
\hline 5. & Total & 18472482.0 & 18472482.0 & 24489292.3 & 24489292.3 \\
\hline
\end{tabular}

Source: Financial statements of the bank for year 1 and year 2

Appendix 4

The situation of assets and liabilities for each currency for the commercial bank

\begin{tabular}{|c|c|r|r|r|r|}
\hline \multirow{3}{*}{ No. } & \multirow{3}{*}{ Currency } & \multicolumn{4}{|c|}{ Thousand lei } \\
\cline { 3 - 6 } & & \multicolumn{1}{|c|}{$\mathbf{1}$} & \multicolumn{1}{|c|}{ Liabilities } \\
\cline { 3 - 6 } & & \multicolumn{1}{|c|}{ Assets } & Liabilities & \multicolumn{1}{|c|}{ Assets } & \multicolumn{1}{|c|}{ L } \\
\hline 1. & RON & 11471556.4 & 11963545.9 & 14955183.4 & 15106398.1 \\
\hline 2. & USD & 3780286.9 & 3103240.9 & 4384088.4 & 4104241.8 \\
\hline 3. & EUR & 2945997.8 & 3208789.7 & 4975773.2 & 5095610.1 \\
\hline 4. & Other currencies & 274640.9 & 196905.5 & 174247.3 & 183042.3 \\
\hline 5. & Total & 18472482.0 & 18472482.0 & 24489292.3 & 24489292.3 \\
\hline
\end{tabular}

Source: Financial statements of the bank for year 1 and year 2 